Eurasscience Journals

Eurasian Journal of Forest Science (2014) 2(2): 1-6

\title{
LIGNOCELLULOSIC FIBERS AND NANOCELLULOSE AS REINFORCING FILLER IN THERMOPLASTIC COMPOSITES
}

\author{
Nadir Ayrilmis ${ }^{1}$, Alireza Ashori ${ }^{2 *}$ \\ ${ }^{1}$ Professor, Ph.D., Department of Wood Mechanics and Technology, Faculty of Forestry, Istanbul University, Bahcekoy, \\ 34473, Sariyer, Istanbul, Turkey Tel: +90 2123382400 (Ext: 25083), Fax: +90 2123382424 E- mail: \\ nadiray@istanbul.edu.tr,*Corresponding author \\ 2 Associate Professor, Ph.D., Department of Chemical Technologies, Iranian Research Organization for Science and \\ Technology (IROST), Tehran, Iran Tel: (+98 21) 5627 5192-3, Fax: (+98 21) 56275191
}

\begin{abstract}
Lignocellulosic fibers have received considerable attention as a substitute for synthetic fiber reinforcements in thermoplastics. As replacements for conventional synthetic fibers like aramid and glass fibers, lignocellulosic fibers are increasingly used for reinforcement in thermoplastics due to their low density, good thermal insulation and mechanical properties, reduced tool wear, unlimited availability, low price, and problem-free disposal. Lignocellulosic fibers also offer economical and environmental advantages over traditional inorganic reinforcements and fillers. As a result of these advantages, lignocellulosic fiber reinforced thermoplastic composites are gaining popularity in automotive, garden decking, fencing, railing, and non-structural building applications, such as exterior window and door profiles, siding. Another class of naturally-sourced reinforcements of recent interest is nanocellulose-based reinforcements. This study provides a short review on developments in the area of lignocellulosic fibers and nanocellulose, and their applications in cellulose based thermoplastic composite industry.
\end{abstract}

Keywords: Lignocellulosic fibers, Nanocellulose, Reinforcing lignocellulosic filler, Thermoplastic composite, Wood

Özet

Son yıllarda doğal liflerin termoplastik kompozitler içerisinde güçlendirici olarak kullanımı giderek artmaktadır. Aramid ve cam lifleri gibi sentetik güçlendiricilerle karşılaştırdığında doğal lifler düşük yoğunluğa sahip olmaları, iyi termal izolasyona ve mekanik özelliklere sahip olmaları, makineleri az aşındırmaları, yenilenebilir olmaları nedeniyle doğada sınırsız bulunmaları, ucuz olmaları ve geri dönüşüm ile tekrar kullanılabilmeleri gibi üstün avantajlarıyla termoplastik endüstrisinde kullanımı hızla artmaktadır. Bahsi geçen önemli avantajlarının bir sonucu olarak selüloz esaslı liflerin, otomobil endüstrisinde koltuk ve kapı iç akşamlarında, bahçe çitleri ile pencere kapı profilleri, havuz kenarları, üst geçitler ve kafeteryalarda döşeme malzemesi, dış cephe kaplaması gibi yapısal olmayan bina uygulamalarında kullanımları hızla artmaktadır. Son yıllarda doğal güçlendiriciler arasında yer alan nanoselüloz de giderek ilgi çekmekte ve ticarileştirilmesi üzerine önemli çalışmalar yapılmaktadır. Bu çalışmada ahşap plastik kompozit gibi selüloz içeren termoplastik kompozit ürünlerde kullanılan selüloz esaslı lifler ve nanoselüloz üzerine gelişmeler hakkında bilgi verişmiştir.

Anahtar kelimeler: Selüloz esaslı lif, Nanoselüloz, Güçlendirici doğal lif, Termoplastik kompozit, odun

eurasscience.com 


\section{INTRODUCTION}

Fibers can be classified into two main groups: man-made and natural. The term 'natural fibers' is used to designate various types of fibers, which naturally come from plants, mineral, and animals (Ashori 2008). All plant fibers are composed of cellulose, hemicelluloses and lignin while animal fibers consist of proteins (hair, silk, and wool). In order to clarify our case, the word 'plant' might be cited as vegetable, cellulosic or lignocellulosic. Lignocellulosic fibers offer the potential to deliver greater added value, sustainability, renewability and lower costs compared with man-made fibers (Bismarck et al. 2006).

Plant fibers can be subdivided into non-wood fibers and wood fibers. Non-wood fibers can be classified according to which part of the plant they are originate from. These include bast (or stem or soft sclerenchyma) fibers, leaf, seed, fruit, root, grass and cereal straw (Peijs et al. 2002). Agricultural residuals such as wheat straw, rice straw, bagasse and corn stalks are also sources of lignocellulosic fibers, although they have a lower cellulose content compared to wood (Panthapulakkal et al. 2006). In this review article, developments in the area of lignocellulosic fibers and nanocellulose, and their applications in cellulose based thermoplastic composite industry are presented.

\section{Wood fibers}

Wood is built up from cells, most of which are fibrous. Wood fiber is a composite material, which is composed of a reinforcement of cellulose microfibril in a cementing matrix of hemicellulose and lignin (Ashori et al. 2006). Lignocellulosic materials contain cellulose, hemicellulose, lignin, and extractives in various amounts and chemical compositions. The properties of the wood flour are dependent not only on the main polymeric components but also on the structural arrangement of these components on the micro and macro-scales. The chemical properties and behavior of wood or non-wood components during pulping and bleaching are very important. The proportions for wood are, on average, $40-50 \%$ cellulose, $20-30 \%$ lignin, and 25-35\% hemicellulose (Ashori 2006).

It is to be noted that lignocellulosic fibers are cylindrical in shape with length to diameter ratios commonly in the range of 10-60 (Fig. 1). Lignocellulosic fibers are usually hollow with walls having a composite, multi-layered structure of commonly three main layers: the middle lamella (ML), the primary layer $(\mathrm{P})$ and the secondary layer $\left(\mathrm{S}_{1}, \mathrm{~S}_{2}\right.$, and $\mathrm{S}_{3}$ ) (Ashori 2006). In living, undamaged plant tissue, the walls taper at the ends of the fiber to form a sealed envelope around the central cavity, or lumen.
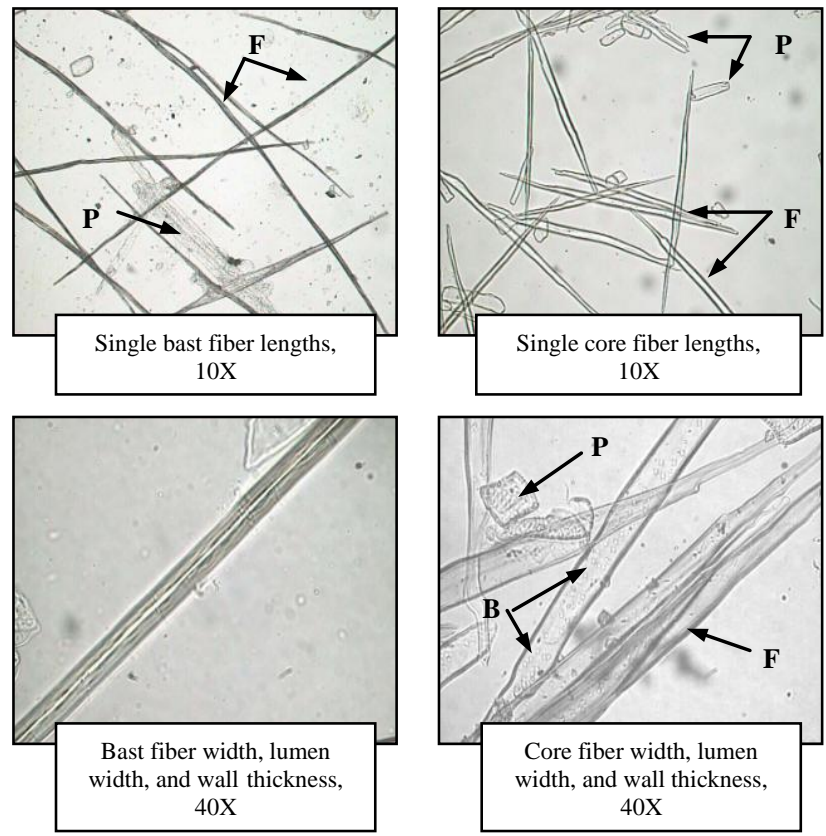

Figure 1. Photomicrograph of kenaf bast and core fibers under different magnifications

(P: parenchyma cells, F: fibers, B: bordered pits).

Each layer of the fiber cell wall is made up of millions of microfibrils that are wound in a semistructured helical fashion around the main fiber axis with varying quantities of lignin and amorphous hemicellulose binding the microfibrils into bundles, called fibrils (Smook 1992).

Cellulose, the most abundant biopolymer on earth, is also the main constituent of wood. It is located predominantly in the secondary wall of the wood fiber (Sjöström 1993). Approximately $45-50 \%$ of extractivefree dry substance in most plant species is cellulose, and it is the most single important component in the fiber cell wall in terms of its volume and effect on the characteristics of wood (Rowell et al. 1997). Cellulose molecules consist of long linear chains of homopolysaccharide, composed of $\beta$-D-glucopyranose units, which are linked by (1-4)-glycosidic bonds. Most of its chemical properties may be related to the hydroxyl groups in each monomer unit and the glycosidic bonds. The glycosidic bonds are not easily broken, thus causing cellulose to be stable under a wide range of 
conditions. However, the hydroxyl groups in cellulose can be readily oxidized, esterified, and converted to ethers. During compounding in an extruder, the thermal and chemical degradation, and mechanical degradation of cellulosic fibers often deteriorate the mechanical properties of cellulosic fibers. Normally, cellulose is relatively insensitive to the effect of heating at moderate temperatures over short periods of time. However, thermal degradation begins to appear as the temperature and duration of heating are increased. At lower temperatures (below $300{ }^{\circ} \mathrm{C}$ ), thermal degradation of cellulosic fibers results in the decomposition of the glycosyl units of cellulose with evolving of water, carbon dioxide and carbon monoxide, when cellulosic fibers are exposed to the effects of heat, air, and moisture (Rowell and Clemons 1992). These reaction products can accelerate the degradation process.

Cellulose has a strong tendency to form intraand inter-molecular hydrogen bonds that are responsible for much of the super-molecular structure, chemical and physical behavior of cellulose (Sjöström 1993). Within the microfibrils in the cell wall, cellulose is arranged into zones that display varying degrees of crystallinity and a degree of polymerization (DP) of 7000-10000 in native (or unpulped) wood. Cellulose of various plant origins (wood and non-wood) exhibits a wide range of crystallinity (20-90\%), which greatly affects its resistance to chemical attack and utility (Tappi 2002). In addition, the tensile strength of wood flour comes primarily from the crystalline cellulose microfibrils.

The lignin contents in different woods range between $20-30 \%$; typically $26-32 \%$ in softwoods and $20-28 \%$ in hardwoods. At the same time, non-wood fibers contain between 5-23\% lignin (Sjöström 1993). Lignin is a highly complex non-crystalline, heterogeneous polymer with non-repeating monomeric units and chemical linkages. Lignin acts as the plastic matrix that, in combination with hemicellulose, binds wood fibers together and provides wood with its structural rigidity and resistance to moisture and microbial attack (Rowell and Clemons 1992). Lignin concentration varies in different morphological regions of the plant and in different types of plant cells. In general, lignin concentration is high in the middle lamella (ML) and primary wall (P), and low in the secondary (S) wall.

Non-cellulosic carbohydrates or hemicelluloses are hetero-polysaccharides, which contain hexosan and pentosan monomer units. The amount of hemicellulose in wood is usually between $20-30 \%$. Softwood hemicellulose consists of both pentosans and hexosans, while hardwood hemicellulose consists mainly of pentosans. Normally hemicellulose can be characterized as a thermoplastic polymer and is similar to cellulose in possessing high backbone rigidity through intermolecular hydrogen bonding. The pentosan content in softwoods is about $7-10 \%$, and in hardwoods about 19-25\% (Tappi 2002). Most hemicelluloses have a DP of about 100-200 (Sjöström 1993) and they are branched and generally do not form crystalline regions.

\section{Nanocellulose}

Over the last decade, and particularly in the last five years, a growing number of research groups worldwide have reported the formation and utilization of celluloses with widths of the fibrils or crystals in the nanometer range. Engineering fiber and design of lignocellulosics or rod-like cellulose nanoparticles and micro fibrils to get high value-added products with special performance can reach new markets through nanotechnology (Duran et al. 2011). It has been shown that the cellulose microfibrils present in wood can be liberated by high-pressure homogenizer procedures. The product, microfibrillated cellulose (MFC), exhibits gel-like characteristics. A second type of nanocellulose, nanocrystalline cellulose (NCC), is generated by the removal of amorphous sections of partially crystalline cellulose by acid hydrolysis. NCC suspensions have liquid-crystalline properties. In contrast to MFC and NCC, which are prepared from already biosynthesized cellulose sources, a third nanocellulose variant, bacterial nanocellulose (BNC), is prepared from lowmolecular-weight resources, such as sugars, by using acetic acid bacteria of the genus luconacetobacter. The in situ biofabrication of $\mathrm{BNC}$ opens up unique possibilities for the control of shape, and the structure of the nanofiber network (Klemm et al. 2011).

Micro/nanofibrils isolated from lignocellulosic fibers have garnered much attention for the use in composites, coatings, resins, and film because of high specific surface areas, renewability and unique mechanical properties in the past two decades (Spence et al. 2011). Nanocrystals are ricelike, needle-shaped and strong with diameters in the 5- to 10-nm range and lengths on the order of 100 to $200 \mathrm{~nm}$, depending on the source. In contrast, nanofibrils, which tend to have roughly 5-nm diameters, as spaghetti-like because they 
are longer (a micrometer or more), flexible, and easily entangled (Jacoby 2014).

Some of the attributes (and benefits) of nanocellulose are (Anonymous 2014a):

- Abundant, sustainable, environmentally and biologically safe, being derived from plant material

- Long fiber structure, providing composite material strength enhancements, like in plastics, glass or concrete

- High tensile strength with a strength/weight ratio being eight times that of steel

- Clear or transparent in water but with manipulation very unique and interesting optic properties due to its structure and with modifications can screen UV rays or enhance color brilliance

- Benign to the human body and thus can be used as a unique carrier for drug delivery systems or for building tissue scaffolding, micro-filters for blood or in strengthening bones

- Safe for human consumption, offering properties that can enhance the food and beverage markets where it can be used for delivery of taste, or in enhancing food textures like in yogurts or salad dressings or as an additive in low-calorie products

- Unique properties for aerogels or hydrogels

- Easily functionalized; meaning it can be manipulated or combined with other polymers for many applications.

Composites, like glass or plastics, can benefit greatly with addition of nanocellulose, one study showing a 3000 times strength gain by adding one ounce of nanocellulose to one pound of plastic. In this example, engineers can significantly reduce the weight of a plastic composite without sacrificing strength (benefiting auto manufacturing, for instance) or keep the mass of plastic the same while dramatically increasing strength. When properly aligned, nanocellulose offers an alternative to even stronger applications, like replacing $\operatorname{Kevlar}{ }^{\circledR}$ from DuPont. It is being investigated by the Department of Defense to use in body armor and ballistic glass. With its transparency, strength and optic properties, nanocellulose is being researched by Pioneer Electronics as a replacement for glass for flexible screens. With these optical and other properties it is a unique additive for inks, paints, dyes or glazing adding strength while enhancing color brilliance. Combined with its safe attributes, it has applications in cosmetics and personal care products (possibly as a sunscreen, for instance) (Anonyomus 2014b).

\section{Microfibrillated cellulose (MFC)}

A cellulose fiber is composed of bundles of microfibrils where the cellulose chains are stabilized laterally by inter and intramolecular hydrogen bonding. Cellulose fibers are turned into nanofibrous forms by chemical and mechanical treatments. One type of such nanofibers is called microfibrillated cellulose (MFC), which can be obtained by a high pressure homogenizing treatment (Iwamoto et al. 2014; Jang et al. 2013). The properties of MFC have been previously reviewed by Siro and Plackett (2010). The MFC consists of moderately degraded long fibrils that have greatly expanded surface area. Typically, traditional MFC consists of cellulose microfibril aggregates with a diameter ranging from 20 to even $100 \mathrm{~nm}$ and length of several micrometers, rather than single nanoscale microfibrils (Kettunen 2013). Microfibrils are comprised of elementary fibrils where monocrystalline domains are linked by amorphous domains

Concerning the production of MFC, several mechanical treatments have been used, such as a twosteps process including a refining and a high-pressure homogenization step, cryocrushing, and grinding methods. Developed in 1983 by Turbak et al. (1983), the homogenization technology allows the production of a network of interconnected cellulose microfibrils. Without any cellulose pre-treatment, the two-steps mechanical process has usually led to the obtention of MFC with the smallest diameters. In general, MFC is obtained from cellulose fibers after a two-step mechanical disintegration process, consisting of an initial refining step followed by a high pressure homogenization step. More recently, there has been a focus on energy-efficient production methods, whereby fibers are pretreated by various physical, chemical, and enzymatic methods before homogenization to decrease the energy consumption. Pretreatments are alkaline pretreatment, oxidative pretreatment, and enzymatic pretreatment (Kwon et al. 2014). The most important characteristics of MFC are the dimensions and distribution of dimensions of the fibrillar material, and the rheology of the resulting dispersion (Klemm et al. 2011). These microfibrils have disordered (amorphous) regions and highly ordered (crystalline) regions. In the crystalline regions, cellulose chains are closely packed together by a strong 
and highly intricate intra- and intermolecular hydrogenbond network, while the amorphous domains are regularly distributed along the microfibrils (Zhou et al. 2012)

The hydrophilic character of MFC constitutes a major obstacle for its use in composite applications. In order to tackle this problem, one strategy involves the chemical modification of MFC's surface hydroxyl groups, in order to prevent hornification phenomena and/or decrease the nanofiber surface hydrophilicity. In the past decades, the chemical modification of MFC has received a significant interest from the scientific community. Thus, many reactions have already been performed in order to permanently modify the surface properties of the MFC (i.e., surface polarity), involving the use of 2,2,6,6-tetramethylpiperidine-1-oxyl (TEMPO) oxidative agent, silane reagents, carboxymethylation, acetylation, isocyanates, poly( $\varepsilon-$ caprolactone) or anhydrides (Tingaut et al. 2011).

\section{Nanocrystalline cellulose (NCC)}

Nanocrystalline celluloses, also known as whiskers, consist of rodlike cellulose crystals with widths and lengths of 5-70 $\mathrm{nm}$ and between $100 \mathrm{~nm}$ and several micrometers, respectively. They are generated by the removal of amorphous sections of a purified cellulose source by acid hydrolysis, often followed by ultrasonic treatment (Klemm et al. 2011). The commercialization of cellulose nanocrystals is still at an early stage, but appears very promising, as the strengthening effect and optical properties of NCC may find use in nanocomposites, paper making, coating additives, security papers, food packaging, and gas barriers. High aspect ratio, low density, low energy consumption, inherent renewability, biodegradability and biocompatibility are the advantages of environmentally-friendly crystalline nanocellulose (CNC) (Zhou and Wu 2012). Bacterial nanocellulose (BNC)-also called bacterial cellulose, microbial cellulose, or biocellulose is formed by aerobic bacteria, such as acetic acid bacteria of the genus Gluconacetobacter and Acetobacter xylinum, as a pure component of their biofilms (Klemm et al. 2011).

During the past decade, CNCs have attracted considerable attention attributed to their unique features. First, CNCs have nanoscale dimensions and excellent mechanical properties. The theoretical value of Young's modulus along the chain axis for perfect native CNCs is estimated to be $167.5 \mathrm{GPa}$, which is even theoretically stronger than steel and similar to
Kevlar, while elastic modulus of native $\mathrm{CNCs}$ from cotton and tunicate reach up to 105 and $143 \mathrm{GPa}$, respectively (Zhou and Wu 2012).

An excellent review on cellulose whiskers summarized the dimensional characteristics with their respective sources, description of isolation processes, hydrolysis conditions, and techniques of determination and performance of this material in suspension and in polymeric matrixes (Duran et al. 2011). Comments on dispersity, related to their tendency towards agglomeration, and their compatibility with commercial hydrophobic polymers were also discussed. A recent review showed that nanocrystalline cellulose exhibited intriguing scientific and engineering discoveries and advancements (Habibi et al. 2010). However, the authors pointed out that, the field is still in its infancy and open to opportunities for new advancements and discoveries. Other authors showed that cellulose nanocrystals are attractive material to incorporate into composites because they can introduce additional strength gains with highly versatile chemical functionality (Duran et al. 2011).

\section{CONCLUSIONS}

Lignocellulosic fibers reinforced thermoplastic composites have received much attention because of their low density, nonabrasive, combustible, nontoxic, low cost, and biodegradable properties.composite manufacturers are seeking to take advantage of the favorable balance of properties (e.g., low density, good mechanical properties) of bast fibers from plants in composite applications. A new building material - WPC has emerged. Another class of naturally-sourced reinforcements of recent interest is nanocellulose-based reinforcements. Application of cellulose nanofibers in polymer reinforcement is a relatively new research field. The main reason to utilize cellulose nanofibers in composite materials is because one can potentially exploit the high stiffness of the cellulose crystal for reinforcement.

\section{References}

Anonymous. (2014a). Noticias de Nanotecnología. www.tecnologianano.com (Accessed June 20, 2014).

Anonymous. (2014b). Silvantris: Primer on NanoFibers and NanoCellulose. Silvantris, LLC, Orem, UT, USA, www.silvantris.com. [Accessed 15 June 2014]. 
Ashori, A. (2006). Non-wood fibers - A potential source of raw material in papermaking. Polymer-Plastics Technology \& Engineering 45(10): 1133-1136.

Ashori, A. (2008). Wood-plastic composites as promising green-composites for automotive industries. Bioresource Technology 99:4661-67.

Ashori, A., Jalaluddin, H., Raverty, W.D., Mohd Nor, M.Y. (2006). Chemical and morphological characteristics of Malaysian cultivated kenaf (Hibiscus cannabinus) fiber. Polymer-Plastics Technology \& Engineering 45:131-34.

Bismarck A., Baltazar, Y.C., Sarlkakis, K. (2006). Green composites as Panacea? Socio-economic aspects of green materials. Environment, Development and Sustainability 8:445-63.

Durán, N., Lemes, A.P., Durán, M., Freer, J., Baeza, J. (2011). A mini review of cellulose nanocrystals and its potential integration as co-product in bioethanol production. Journal of the Chilean Chemical Society 56:672-77.

Habibi, Y., Lucia, L.A., Rojas, O.J. (2010). Cellulose nanocrystals: chemistry, self-assembly, and applications. Chemical Reviews 110: 3479-500.

Iwamoto, S., Yamamoto, S., Lee, S.H., Endo, T. (2014). Mechanical properties of polypropylene composites reinforced by surface-coated microfibrillated cellulose. Composites Part A: Applied Science and Manufacturing 59: 26-29.

Jacoby, M. (2014). Nano from the forest. Chemical \& Engineering News 92:9-12.

Jang, J.H., Lee, S.H., Endo, T., Kim, N.H. (2013). Characteristics of microfibrillated cellulosic fibers and paper sheets from Korean white pine. Wood Science and Technology 47: 925-37.

Kettunen, M. (2013). Cellulose nanofibrils as a functional material. PhD diss., Aalto University, Helsinki.

Klemm, D., Kramer, F., Moritz, S., Lindström, T., Ankerfors, M., Gray, D., Dorris, A. (2011). Nanocelluloses: a new family of nature-based materials. Angewandte Chemie Int Edition 50: 5438 66.

Kwon, J.H., Lee, S.H., Ayrilmis, N., Han, T.H. (2014). Effect of microfibrillated cellulose content on the bonding performance of urea-formaldehyde resin. Proceedings of the $57^{\text {th }}$ International Convention of Society of Wood Science and Technology, Technical University in Zvolen June 23-27, Zvolen, Slovakia, p:683-690.
Panthapulakkal, S., Zereshkian, A., Sain, M. (2006). Preparation and characterization of wheat straw fibers for reinforcing application in injection molded thermoplastic composites. Bioresource Technology 97:26572 .

Peijs, T., Cabrera, N., Alcock, B., Schimanski, T., Loos, J. (2002). In: Proceedings of $9^{\text {th }}$ International Conference on Fibre Reinforced Composites - FRC 2002, Gibson, A.G. (Ed.); March 26-28, Newcastle upon Tyne, UK.

Rowell, R.M., Clemons, C.M. (1992). Chemical modification of wood fiber for thermoplasticity, compatibilization with plastics and dimensional stability, In: Maloney, T.M. (Ed.), Proceedings of the International Particleboard/Composite Materials Symposium, Pullman, WA, pp. 251-259.

Rowell, R.M., Young, R.A., Rowell, J.K. (1997). Paper and composites from agrobased resources. Boca Raton: CRC Press.

Sjöström, E. (1993). Wood Chemistry: Fundamentals and Applications. $2^{\text {nd }}$ ed. San Diego: Academic publisher.

Smook, G.A. (1992). Handbook for Pulp and Paper Technologists. $2^{\text {nd }}$ ed. Vancouver: Angus Wilde.

Spence, K.L., Venditti, R.A., Rojas,O.J., Habibi, Y., Pawlak, J.J. (2011). A comparative study of energy consumption and physical properties of microfibrillated cellulose produced by different processing methods. Cellulose, 18:1097-111.

TAPPI Test Methods. (2002). Tappi Press: Atlanta. GA.

Turbak, A.F., Snyder, F.W.,Sandberg, K.R. (1983). Microfibrillated cellulose, a new cellulose product: Properties, uses and commercial potential. Journal of Applied Applied Polymer Science 37:815-27.

Zhou, C., Wu, Q. (2012). Chapter 6: Recent development in applications of cellulose nanocrystals for advanced polymer-based nanocomposites by novel fabrication strategies. Nanotechnology and Nanomaterials: Nanocrystals - Synthesis, Characterization and Applications (Ed: Nerella, S.). Rijeka: Intech Publisher, p: $103-120$.

Submitted: 22.09.2014

Accepted: 03.11.2014 